\title{
O retorno ao passado em Barco a seco e o jogo de construção e desconstrução narrativa Carlos Palacios ${ }^{1}$
}

\author{
the sleeping and the dead \\ Are but as pictures \\ William Shakespeare, Macbeth
}

\section{A narrativa como ato de organizar o mundo ${ }^{2}$}

Há uma cena, em O ovo da serpente, de Ingmar Bergman, na qual um investigador de polícia demonstra sua angústia e preocupação diante de toda a instabilidade que paira sobre a Alemanha em 1923: a enorme inflação, o desemprego, a falta de serviços públicos, a ameaça bolchevique, a insurgência de Hitler e seu exército. Em face disso, o que faz o inspetor Bauer? A personagem responde: "O inspetor Bauer faz o seu trabalho. Trata-se de criar um pouco de ordem e de sensatez no meio do caos". Fazer seu trabalho significa resolver alguns assassinatos que não aparentam sentido; construir a narrativa que resolva um caso, que dê forma e coesão a uma parcela de um mundo que está prestes a entrar em colapso. De fato, ocupar-se dos mortos é uma tarefa muito mais estabilizadora do que se debruçar sobre uma realidade viva, em constante transformação. Conviver com esse real é ser cúmplice dele - e ser cúmplice do terror não é para qualquer um, por isso, o inspetor Bauer dedica-se aos mortos e o judeu Abel Rosenberg à bebida.

O investigador está sempre em busca de uma verdade, de uma relação causal de fatos. Gaspar Dias, protagonista de Barco a seco, de Rubens Figueiredo, também é uma espécie de investigador - um perito de obras de arte, especialista no pintor Emilio Vega. Seu objetivo é construir uma imagem coesa e fechada de seu objeto e, como o inspetor de $O$ ovo da serpente, ele o faz em um morto. "Um morto é irrefutável" (Figueiredo, R., 2001, p. 17), afirma Gaspar, na esperança de se agarrar a

\footnotetext{
${ }^{1}$ Doutorando em Letras Vernáculas pela Universidade Federal do Rio de Janeiro (UFRJ), Rio de Janeiro, RJ, Brasil. E-mail: palaciosccm@gmail.com

${ }^{2}$ Este artigo tem origem na dissertação do autor, intitulada Ficção, realismo e verdade: caminhos da literatura brasileira no século XXI, defendida em 2014, junto à Universidade Federal do Rio de Janeiro, sob orientação do prof. Godofredo de Oliveira Neto.
} 
uma realidade sólida, em um mundo em que tudo parece se esvair como as ondas do mar que Emilio Vega tanto reproduziu em suas pinturas. A narrativa de Barco a seco é a narrativa de diversas ficções que se encontram, se constroem e se desconstroem. Todas as personagens ordenam o mundo de alguma forma ao criarem suas ficções, mesmo que seja uma ordenação caótica. Ao ordená-lo, elas classificam o que é falso e o que é verdadeiro, o que é legítimo e o que é ilegítimo, o que é honesto e o que é desonesto. A multiplicidade dessas ficções provenientes da ação de cada personagem não converge, contudo, em polifonia: Mikhail Bakhtin (2013) conferia a qualidade de polifônico ao romance de Dostoiévski a partir de uma multiplicidade de vozes e psicologias que se confrontam e se complementam, mas que só é possível graças à existência de personagens cujas vozes são independentes da figura central do narrador. Em Barco a seco, todas as demais vozes das personagens recebem o tratamento da mediação do protagonista-narrador Gaspar Dias, que é o principal organizador de toda a realidade do romance. O sentido que lhes é dado provém do olhar e dos critérios de classificação de Gaspar, tal qual o faz ao classificar obras de arte como autênticas ou falsas.

Gaspar articula diretamente três narrativas que se relacionam entre si: a de seu passado, de criança órfã adotada por uma família pobre; a do pintor Emilio Vega, que viveu na mesma cidade e teria morrido jovem, afogado enquanto nadava no mar; e a narrativa do presente, que reúne a reconstrução das duas do passado e as de todas as demais personagens. Dessas, destaca-se Angelina, espécie de figura materna de Gaspar, que o "adotou" no meio acadêmico e o guiou pelos caminhos em direção à arte de Vega. Nessas três narrativas, o protagonista faz uso de um mesmo tipo de linguagem, uma mesma técnica de representação, que Ivone Daré Rabello define como uma "escrita precisa":

a "escrita precisa" efetivamente engloba um ponto de vista segundo o qual a corrente da vida - aleatória, banal ou simplesmente estranha - precisa ser pensada, refletida, organizada com exatidão e "dignidade" linguística na contracorrente das experiências-limítrofes, desorganizadas, brutais, aparentemente governadas pelo acaso, tal como os indivíduos as vivem (Rabello, 2007, p. 131).

O perito assume o papel de um narrador clássico para, assim, organizar e classificar o mundo a partir de critérios preestabelecidos. Ele 
rejeita tudo aquilo que pode desconcertar a ficção do presente em que vive - por exemplo, com sua namorada, Ester, prefere não conversar sobre seus passados, pois estes poderiam vir a colidir com a ordem atual:

Ester é viúva e do seu ex-marido não pergunto nem o nome. Como não o conheci, sua morte é para mim tão abstrata quanto a sua vida. Daí o paladar de adultério que às vezes descubro em meu caso com Ester. Ela, por sua vez, desistiu bem cedo de fazer perguntas mais específicas sobre o meu passado, o que evita para mim o desconforto de buscar subterfúgios ou mentiras complicadas - coisa que nem por isso eu hesitaria em fazer. Não poderia ser mais conveniente. Assim, nem eu nem ela nos vemos na necessidade de aumentar a população de fraudes deste mundo (Figueiredo, R., 2001, p. 43).

Ambos desejam viver um presente fixo e inabalável. Como perito, Gaspar não busca a verdade a qualquer custo, pois isso exigiria questionamentos do presente e retornos ao passado; ele busca é uma ordem que possa ser experimentada como legítima e única, embora se saiba que é pura construção: "onde encontrar um prazer que, de um jeito ou de outro, não seja desonesto?" (Figueiredo, R., 2001, p. 46). Ester frequenta um asilo e visita idosos abandonados, conversa e escuta o que eles têm a dizer; um ato de solidariedade que, de acordo com Gaspar, esconde um prazer egoísta de quem estaria apenas pensando na própria satisfação. Embora almejem o sólido e o único, toda ação e toda construção parecem esconder um duplo, uma contradição capaz de desestabilizar a narrativa proposta. Como evitar que esse conflito ocorra?

Não há como apagar o passado. Rabello (2007, p. 134) afirma que, para se construir como imagem, o protagonista "precisa soterrar seu passado". Faz-se necessário aqui estabelecer uma posição contrária a essa ideia. Como já dito, Gaspar deseja construir uma imagem coerente para si e, de fato, seu difícil passado de pobreza é uma ameaça a esse projeto, mas ele próprio afirma: "o passado respira todo o tempo às minhas costas" (Figueiredo, R., 2001, p. 38). A experiência jamais poderá ser eliminada, mas, sim, reconstruída. É preciso, então, domesticar esse passado, construir uma narrativa causal que o explique e o cubra de sentidos e o faça transcorrer em um único tempo: o passado estático, incapaz de retornar ao presente. Congelar os acontecimentos em um 
tempo anterior, dissociado da ordem atual, essa é a alternativa que o narrador encontra para preservar a narrativa do presente.

A memória, de acordo com Bachelard (1993, p. 28-29), não registra uma duração de tempo concreta no sentido bergsoniano, ela só pode ser pensada na linha de um tempo abstrato privado de qualquer espessura. Esse tempo abstrato é incontrolável; ausente de concretude, instável, ele pode retornar e se misturar ao presente. Teóricos de linha lacaniana, como Slavoj Žižek (1997), já ressaltaram que a narrativa pode surgir para resolver os antagonismos de alguma ordem social ou individual ao rearranjar os acontecimentos em uma sucessão temporal. É a fantasia, espécie de falsificação do real, que reveste essa ordem de sentido e coesão (Žižek, 1997, p. 10-11), sendo o fio condutor das diversas formas de narrativa desenvolvidas no romance. Cada personagem é encoberta de uma fantasia específica, logo, de uma narrativa própria, que pode se harmonizar ou entrar em conflito com as demais.

Se Gaspar, Ester e Angelina buscam uma ordem estabilizada - a estabilidade financeira, social, afetiva -, Inácio Cabrera e Humberto agem em sentido contrário. Humberto é filho de Angelina e representa uma figura desestruturada dentro da narrativa da mãe; ele é incapaz de se manter em um emprego e se sustentar, além de cometer erros e desonestidades financeiras que levam a mãe ao risco da falência. A saída de Angelina é criar uma fantasia que forje uma estabilidade à vida do filho: inventa um emprego para ele em uma empresa de verdade, na qual, porém, ele não realiza função nenhuma, e cujo salário é ela mesma quem paga. Já Inácio Cabrera é a figura de um velho que traz, a todo o momento, informações e supostos trabalhos novos de Emilio Vega; é como se o objeto sobre o qual Gaspar se debruça e com o qual se realiza - um objeto morto e incapaz de traí-lo - retornasse amiúde à vida e revelasse novos contornos, rostos e atitudes.

O tema de Barco a seco é o tema do duplo em seus mais diversos sentidos, mas, principalmente, o duplo da narrativa, que se dá pela sua construção e desconstrução: a primeira é uma necessidade do espírito de dar ordem e sentido aos signos da realidade; a segunda é uma condição inevitável de toda narrativa que, erguida nos moldes clássicos e realistas, ${ }^{3}$

\footnotetext{
3 Entendemos aqui que uma "narrativa clássica e realista" é uma narrativa que busca uma concatenação lógica de acontecimentos, uma relação de causa e efeito, na qual a trama está a serviço da fábula, esta que deve ter uma forma acabada e plena de sentidos.
} 
resolve ir além e romper os limites da fantasia que a originou. Em Mágico de $\mathrm{Oz}$, Dorothy se realiza na fantasia além do arco-íris, mas, inevitavelmente, retorna ao seu local de origem, que é a vida no Kansas; já a fantasia de Gaspar Dias se dá na organização e atribuição de sentidos ao passado - a biografia de Vega e a autobiografia de sua infância. No entanto, essa mesma organização, como o sonho fugaz de Dorothy, jamais é plena, pois a linha tênue da fantasia é facilmente rompida: "Iludido pela sensação de segurança de me mover em um mundo de estátuas, tentado pelo prazer de desdenhar todos os avisos, resolvi ir para o outro lado do cordão imaginário. Esqueci que estava nadando fazia certo tempo" (Figueiredo, R., 2001, p. 10-11). Ao entrar para o outro lado, a ordem segura se converte em instabilidade:

Quando vi já era tarde. Senti o impulso, a água que se encolhia por baixo de mim e, de repente, a superfície do mar deslizou por uma rampa. Uma esteira de água correu, dando início ao que parecia uma curva enorme, e me puxou para trás, ignorando os tapas que estalavam na ponta das minhas braçadas (Figueiredo, R., 2001, p. 11).

O romance de Rubens Figueiredo transita sempre por duas zonas opostas, de fronteiras frágeis e identidades imprecisas: passado e presente, real e imaginário, falso e verdadeiro se cruzam em um conflito infinito e insolúvel. Para nos aprofundarmos mais nessa estrutura binária da obra, é necessário discutir o principal elemento articulador desse conflito: o tempo. Como as ondas do mar que ameaçam a estabilidade de Gaspar, o tempo realiza um movimento que traga, envolve, baralha e devolve as marcas do real e do ficcional.

\section{O retorno ao passado}

De acordo com Octavio Paz (2013), a história da literatura moderna é a história das oscilações entre dois extremos, a tentação revolucionária e a tentação religiosa. A primeira está no olhar para o futuro: a modernidade é autocrítica e autoquestionadora, busca sempre se destruir e se refazer em um tempo novo e ideal, que é o futuro; a segunda está no resgate da inocência, no retorno a um passado mítico anterior à queda. As vanguardas artísticas e as utopias políticas do século XX ilustram essa ideia revolucionária associada ao futuro, a partir de uma cisão com o passado e a afirmação de que, de agora em diante, tudo será diferente sociedade e arte se livrarão de seus atrasos e atingirão seu estado ideal. O 
apreço pela nostalgia nos dias de hoje, contudo, associa-se mais à tentação religiosa, já que o futuro passa a se tornar menos promissor, ou até ameaçador, levando-nos a procurar conforto em nossas memórias. Andreas Huyssen (2000, p. 17-18) fala também sobre essa contraposição nos dois períodos de nossa história recente:

Se a consciência temporal da alta modernidade no ocidente procurou garantir o futuro, então, pode-se argumentar que a consciência temporal do final do século XX envolve a não menos perigosa tarefa de assumir a responsabilidade pelo passado. Inevitavelmente ambas as tentativas são assombradas pelo fracasso.

Se de fato a alta modernidade já foi superada e hoje nos encontramos em um momento de crise em relação a seus valores, ou se até essa crise já se encontra em crise e a pós-modernidade também já está em vias de se tornar passado e fonte de nostalgia, pouco importa nesse momento, não cabendo aqui nos aprofundar em tais questões. Não seria correto considerar o mergulho no passado por Gaspar Dias como essencialmente nostálgico, resgate de alguma inocência perdida - não há nenhuma saudade ou idealização em torno de sua infância pobre. $\mathrm{O}$ que busca, então, a personagem no retorno ao passado? Huyssen aborda uma teoria de Hermann Lübbe acerca da ideia de "musealização" com o objetivo de contrapô-la, mas a discussão pode servir como um interessante ponto de partida.

Já foi discutida, na seção anterior, a ideia de que o protagonista de Barco a seco busca organizar a realidade passada, criando uma narrativa coesa e de sentidos fechados. Para que atinja esse objetivo, o passado deve se mostrar estável, estratificado, como uma série de imagens congeladas e estátuas imóveis, tais quais as que são exibidas nas galerias de um museu. É nesze caso que a musealização possui coerência, ainda mais se pensarmos que Gaspar Dias busca reconstruir a vida de um artista plástico, o que funciona também como metáfora para a ideia aqui abordada. "Na teoria de Lübbe, o museu contemporâneo compensa esta perda de estabilidade. Ele oferece formas tradicionais de identidade cultural a um sujeito moderno desestabilizado" (Huyssen, 2000, p. 29). Por ser um indivíduo instável, sem identidade fixa, cujo passado de pobreza entra em conflito com o presente de ascensão social, Gaspar Dias buscaria então, no retorno ao passado, a estabilização de sua identidade em um mundo de imagens e sentidos fugazes. Seria próximo 
ao que Huyssen afirma a respeito da obsessão da memória em torno do século XX e suas diversas tragédias: que conforto trariam as memórias e os museus que resgatam, por exemplo, a barbárie do holocausto? Lembrar-se do holocausto, certamente, não traz conforto, mas estabilizálo e inseri-lo em um conjunto de signos fixos capazes de construir uma identidade coesa seria, talvez, como pacificá-lo. É como se fosse possível domesticar o passado para que ele não volte para nos assombrar - ou, no caso do holocausto, para que justamente nos assombre, mas com um objetivo claro, de uma forma que tenhamos controle.

Huyssen termina considerando o argumento de Lübbe demasiado simples e ideológico, por atribuir um valor e um poder quase idealizado à prática da memória, esta que também estaria sujeita à desestabilização do mundo contemporâneo: “A própria musealização é sugada neste cada vez mais veloz redemoinho de imagens, espetáculos e eventos e, portanto, está sempre em perigo de perder a sua capacidade de garantir a estabilidade cultural ao longo do tempo" (Huyssen, 2000, p. 30). De fato, essa prática não garante a estabilidade cultural e a identidade individual e coletiva - o que é confirmado no final do romance de Rubens Figueiredo, como abordaremos mais à frente -, porém isso não desqualifica a ideia de que tal atividade memorialista tem esse propósito como ponto de partida: a iminência de um fracasso não desqualifica o ato que o originou. A ambição de Gaspar Dias pode realmente ser a de pacificar o seu passado e construir uma identidade própria, embora seja inevitável que, no fim, tudo termine em ruínas.

Essa teoria dá conta do propósito do protagonista de retornar ao próprio passado, mas é insuficiente quando nos atentamos ao fato de que ele não apenas direciona o olhar para a sua origem, mas para a de um Outro, o pintor Emilio Vega. Por que reconstruir o passado de outra pessoa? Qual o propósito de musealizar a vida de alguém com a qual nunca teve contato? Em que o ato de construir uma identidade fixa para Vega será útil para a construção da identidade pessoal de Gaspar Dias? Eis que o problema inicial se torna um pouco mais complexo.

Octavio Paz diz que o homem é o único ser que é busca de outro, cuja natureza consiste em aspirar a se realizar em outro. "O homem é nostalgia e busca de comunhão" (Paz, 1984, p. 175). A nostalgia de Gaspar consiste em um retorno ao passado de Vega, espécie de tempo mítico e ideal; e a comunhão, em se realizar na figura do pintor: "Seja como for, Emilio Vega parecia talhado para me erguer e me salvar" 
(Figueiredo, R., 2001, p. 35). Faz-se necessário questionar sobre que espécie de salvação a personagem se refere. Graças à ajuda de Angelina, e apoiando-se na imagem de Emilio Vega, Gaspar Dias supera a infância miserável e atinge uma considerável ascensão social - consegue alugar um apartamento e ter um carro, um emprego e uma namorada. Como no romance familiar de Freud, Gaspar é o órfão que reencontra a figura da mãe, representada por Angelina, e se lança em uma busca pela imagem do pai, representada por Emilio Vega; como no complexo de Édipo, a busca pela figura paterna é, automaticamente, o desejo de ocupar o lugar dessa figura perfeita e intocável. ${ }^{4}$

Se o museu do passado de Lübbe resultaria, de acordo com Huyssen, em um inevitável fracasso, a arqueologia da figura paterna também não será menos frustrante, caindo inevitavelmente na metáfora da castração. Em suma, ao almejar a figura de Vega e ocupar seu lugar - seja intencionalmente ou não -, o protagonista busca construir uma narrativa na qual uma atribuição de papeis irá reconstruir sua ficção pessoal e superar os vazios e as frustrações do real - tal qual o faz a criança após a queda no universo familiar.

É importante nos debruçarmos sobre essa relação do protagonista de Barco a seco com a narrativa da criança desenvolvida por Freud. Marthe Robert (2007) distingue duas formas de romance que se relacionam a dois conflitos - ou quedas - pelos quais a criança passa em seus primeiros anos: o romance da criança perdida e o do bastardo. De acordo com a psicanálise de Freud, a criança experimenta sua primeira frustração quando descobre que não só não é o único ser amado no universo de seus pais como também os próprios pais não são únicos: "um início de experiência social ensina-lhe que existem outros, uma multidão de outros entre os quais muitos são de certa forma superiores aos seus, detendo mais espiritualidade, mais bondades, mais fortuna ou status" (Robert, 2007, p. 36). A criança, então, dota-se da capacidade de sonhar e contar histórias, criando uma narrativa para si própria que a mantenha como criatura especial e merecedora do paraíso:

\footnotetext{
${ }^{4}$ Freud (1997) considera esse "romance familiar" não como uma experiência patológica, mas universal e normal da vida infantil. Desse modo, tratar-se-ia de uma artimanha a que a imaginação recorre a fim de resolver a grande crise do crescimento humano tal como determina o "complexo de Édipo" - ou seja, vencer suas frustrações e impossibilidades em um mundo que começa a ser revestido de significados.
} 
irreconhecíveis a seus olhos a partir do momento em que lhes descerra um rosto humano, seus pais lhe parecem tão mudados que ela não consegue mais reconhecer como seus, concluindo daí que não são seus verdadeiros pais, mas literalmente estranhos, pessoas quaisquer com as quais nada tem em comum a não ser pelo fato de a terem escolhido e educado. [...] ela pode doravante ver-se como uma criança perdida e abandonada, ou adotada, a quem sua verdadeira família, monárquica naturalmente, ou nobre, ou poderosa de algum jeito, se revelará um dia com estrépito para introduzi-la finalmente em suas fileiras (Robert, 2007, p. 36-37).

A essa espécie de romance, ou apenas uma característica que pode se misturar ao seguinte, a autora associa o caráter de evasão da narrativa, capaz de romper com as leis e limites de nossa realidade, pois a criança rejeita sua origem por inteiro e passa a ter plenos poderes para reconstruir e florear cada elemento de sua biografia pessoal. Já o segundo romance tem início quando a criança conhece a sexualidade e, com ela, a noção de diferença. Ao compreender as diferenças entre os sexos, a figura da mãe como geradora do filho ganha força e a criança assume a dificuldade de manter a fantasia inicial de que não pertenceria àquela que a gerou, passando a direcionar sua incredulidade para a figura do pai:

Decide então respeitar a mãe - afastando-a do campo de suas operações - para fazer o pai receber sozinho a promoção social ou o enobrecimento, que permanece o melhor meio de servir a seus planos. [...] com uma mãe plebeia e um pai-rei - quimérico, portanto, e tanto mais ausente quanto mais superiormente graduado -, ela atribui-se a um nascimento ilegítimo que lança sua pseudo-biografia em novos caminhos, em que novas turbulências naturalmente a esperam (Robert, 2007, p. 39).

Essa digressão em torno da teoria de Freud serve para associarmos a narrativa de Gaspar Dias a esse segundo romance, o do Bastardo. Cabe ressaltar que as ideias de Marthe Robert são mais complexas e menos simplistas do que parecem aqui. O propósito da autora não é definir regras aos romances, mas, justamente, destacar que essas duas formas de ficção caracterizam-se por não possuírem nenhuma espécie de lei, já que a criança é dotada de todo o tipo de poder para criar sua narrativa pessoal. O romance do bastardo caracteriza-se por um conflito entre o protagonista - a criança -, uma figura presente, dotada de todas as 
falhas e defeitos de um ser que habita nosso mundo - a mãe - e uma figura ausente, idealizada e almejada - o pai. Em Barco a seco, por um lado, Gaspar experimenta a proximidade com Angelina, figura materna imperfeita, incapaz de cumprir adequadamente seu papel de mãe em relação a seu filho Humberto; por outro, busca a realização na imagem do pai distante e inacessível, Emilio Vega, e o faz por intermédio da mãe, personagem que lhe concede estabilidade econômica e pessoal.

O herói da fábula do Bastardo "faz", portanto, claramente um romance, no sentido concebido pelo arrivista da locução: ele "sobe" na vida por meio das mulheres ou, mais exatamente, da mulher que concentra em si toda a sedução das outras, não menos, é verdade, que a natureza essencialmente falível e enganadora da feminilidade (com "eterno feminino" e misoginia renovando aqui sua velha aliança). Entretanto, essa conquista puramente social não esgota de forma alguma seu apetite de poder, ainda que permaneça sua principal preocupação. Ele visa, além disso, o status absoluto da criação, e o obtém pelo ato imaginário mais simples ao se apoderar dessa fonte de todo poder criador que é, a seus olhos, a potência viril paterna (Robert, 2007, p. 44).

A definição da fábula do bastardo poderia ser o resumo da narrativa de Gaspar Dias em Barco a Seco. E a fábula que a personagem busca construir não é como a da criança perdida, que dispõe de um poder maior de evasão da realidade: Gaspar cria sua narrativa seguindo propósitos realistas. Ele recria sua infância sem nostalgia e idealização, buscando reconstruir os acontecimentos exatamente como considera que os experimentou; e recria a de Vega seguindo uma ordem lógica de causas e efeitos, sem dar espaço para contradições ou ambiguidades. Em suma, ele procura substituir a realidade insatisfatória por outra que o satisfaça, mas que siga as mesmas regras e limitações da anterior e, assim, torne-se tão crível quanto essa. Como um narrador realista, onisciente e detentor de todos os poderes de criação, ele segue em direção a seu objeto de desejo: "Eu, por um lado, caçava documentos capazes de cunhar em aço o relevo de um Vega genuíno, as feições puras, brutas, loucas que fossem, dane-se - mas de um Emilio Vega que saísse do molde das minhas mãos, e que por isso, não nego, vivesse sempre sob o meu poder" (Figueiredo, R., 2001, p. 121).

A realidade do presente é inapreensível, a do futuro é incerta, resta ao indivíduo a ilusão de se apoderar da do passado. Em um movimento 
duplo, ele busca congelar a memória de sua infância, distanciando-a do presente, para construir e dar vida a uma nova memória, a partir do retorno a outro passado, ainda mítico e inocente, como se cedesse à tentação religiosa a que se referia Octavio Paz. Neste, ocorre novamente uma ação dupla: criar uma nova figura paterna, ao mesmo tempo em que a própria identidade do criador, que representa o papel de uma criança, confunde-se com a da criação. Gaspar Dias é um perito, um investigador que busca a verdade, mas somente a verdade que interessa para a sua narrativa, por isso, seu questionamento sobre a possibilidade de existir um prazer que não seja desonesto. Deleuze (2003) afirmou que só são usufruídos os prazeres que correspondem à descoberta da verdade, e a verdade de Gaspar é desonesta - é única e não admite questionamentos. Ele aceita aquelas narrativas que, senão o legitimam, ao menos não desestabilizam a sua, como as de Angelina e Ester, pessoas que mantém próximas a si; contudo, abomina Humberto e Inácio Cabrera, o primeiro por colocar em risco sua figura materna, o segundo por fazer o mesmo em relação à outra figura que é a mais desejada e disputada - o pai, Emilio Vega. Aonde chegará Gaspar na construção de sua realidade e verdade pessoal? Ele não deseja apenas o instante eterno, como na consagração do instante de Octavio Paz. ${ }^{5}$ Em vez de imortalidade - vitória sobre o futuro -, ele busca vencer o passado em uma narrativa que se prolonga até o fim. Mas o prolongamento exige construção, o perito deve se tornar também um falsificador: eis o conflito insolúvel, que só encontrará seu fim na própria traição.

\section{O retorno do passado... e as ruínas}

Trata-se, nos dias de hoje, de um lugar-comum a afirmação de que o romance encontra-se em crise, e a de que as narrativas atuais não são mais capazes de contar histórias como antes. A ideia não é absolutamente falsa, mas nem por isso totalmente verdadeira: assim como a modernidade, a crise não seria uma condição inerente ao romance? Como ressalta Vera Lúcia Follain de Figueiredo (2001),

\footnotetext{
${ }^{5}$ A "consagração do instante" é uma tese de Octavio Paz, o qual afirma que, por meio da arte, o homem luta contra o fluxo do tempo e assim cria o tempo mítico, que é o tempo da poesia, da ficção - enfim, o tempo da arte. Ele não evita a morte, não alcança a vida eterna, "mas cria um instante único e irrepetível e assim dá origem à história" (Paz, 1996, p. 56).
} 
afirmar que o romance esteja hoje em crise é uma tautologia, “já que até Dom Quixote, considerado o primeiro romance moderno, seria resultado do abandono progressivo do postulado da unidade da consciência, que provocou a fratura da convenção épica do romance de cavalaria". A crise que levaria a ficção a se questionar é percebida também por Jorge Luis Borges não apenas em Dom Quixote mas também em outros paradigmas da ficção, como Hamlet e Mil e uma noites. Na segunda parte de Quixote, Borges afirma que os protagonistas já leram a primeira e, por isso, também são leitores da própria ficção em que atuam. Algo semelhante ocorreria nas outras duas:

Aqui é inevitável lembrar o caso de Shakespeare, que inclui no palco de Hamlet outro palco, onde se representa uma tragédia que é mais ou menos a de Hamlet; [...] Algo parecido o acaso produziu nas Mil e uma noites. [...] A necessidade de contemplar 1001 seções obrigou os copistas da obra a todo tipo de interpolações. Nenhuma, porém, tão perturbadora quanto a da noite 602, mágica entre todas. Nessa noite, o rei ouve da boca da rainha a sua própria história. Ouve o começo da história, que abrange todas as demais, e também - de forma monstruosa - a de si mesmo (Borges, 2007, p. 63-64).

Os exemplos de Borges demonstram que não é exclusividade de nossos tempos o ato da literatura de olhar para si própria e se reconhecer, abertamente, como construção à parte do real. Seria essa prática uma compreensão de seus próprios limites, como se a literatura deixasse claro que jamais atingirá a "verdadeira realidade"? Borges oferece outra resposta:

Por que nos inquieta que o mapa esteja incluído no mapa e as 1001 noites no livro das Mil e uma noites? Por que nos inquieta que Dom Quixote seja leitor do Quixote e Hamlet espectador de Hamlet? Creio ter dado com a causa: tais inversões sugerem que, se os personagens de uma ficção podem ser leitores ou espectadores, nós, seus leitores ou espectadores, podemos ser fictícios (Borges, 2007, p. 64-65).

Se o universo extratextual pode ser tão fictício quanto o universo textual de uma obra, então olhar para si mesma não diminui nem impõe limites à literatura, mas a engrandece e dignifica. Ao mesmo tempo que reconhece seu fracasso como construção do real, a literatura se equipara a esse real, ao também sugeri-lo como ficção. $O$ fracasso da narrativa de 
Gaspar Dias é revelado quando ela se converte em ruínas, na medida em que a realidade do passado ganha contornos mais nítidos, formas mais acabadas, em suma, adquire vida. Eis a contradição: quanto mais acabada, mais instável se torna a narrativa; dona de uma verdade própria, mais sujeita ela fica ao encontro de novas verdades.

Andreas Huyssen já havia dito que a responsabilidade pelo passado é assombrada pelo fracasso; nesse sentido converge Marthe Robert (2007, p. 46), ao afirmar que o romance infantil, tanto o do Bastardo quanto o da Criança Perdida, tende inevitavelmente a se desfazer: "O imitador enfeitiçado pela magia de seu culto infantil fica impotente para se libertar: o romance do qual ele queria fazer um ato nunca é senão uma despedida impossível, que ele pode apenas querer prolongar". Mesmo desprezando a figura de Inácio, que lhe traz instabilidade, Gaspar não deixa de se aproximar do homem, em uma esperança - falsa ou não, consciente ou não - de dar mais vida à imagem de Emilio Vega. Em certo momento, Inácio deixa um pedaço de papel misterioso com Gaspar; em vez de ignorar o que pode ser algo supérfluo ou prejudicial, o protagonista corre atrás do significado, tenta entrar em contato com Inácio, até, finalmente, marcar um encontro. Trata-se do encontro que levará às ruínas.

As duas personagens se encontram em um casarão velho e a descrição inicial do ambiente já leva à ideia de algo que está prestes a se desfazer: "um casarão em ruínas, já sem telhado, onde apenas dois homens com picaretas se dedicavam, pelo visto, a uma demolição" (Figueiredo, 2001, p. 171). Após os dois estabelecerem um contato inicial, Inácio informa que as paredes do local serão demolidas, o que leva Gaspar a exibir um pensamento revelador:

Para contrariar, respondi que, naquele ritmo, ainda haviam de demorar bastante. O que restava do casarão se eriçava em tantas arestas, enroscava-se em tantas cornijas e volutas, subia em paredes tão grossas e sua massa aderia tão compacta à pedra e ao pó que dava até uma certa pena daqueles dois demolidores. Mesmo assim, qualquer um sabia muito bem que era só uma questão de tempo (Figueiredo, R., 2001, p. 171).

A personagem reforça sua crença na estabilidade e na solidez das coisas, características que tanto lutou para conceder à realidade que buscava construir. Mas, ao final do raciocínio, deixa transparecer a 
inevitabilidade do fim: era questão de tempo para tudo cair por terra. É preciso questionar o porquê desse desmoronamento inevitável.

Não basta, para a memória, o mero retorno ao passado. É necessário também que esse passado se atualize no presente. "O passado da memória é, pois, duplamente relativo: relativo ao presente que foi, mas também relativo ao presente com referência ao que agora é passado. $\mathrm{O}$ que vale dizer que essa memória não se apodera diretamente do passado: ela o recompõe com os presentes" (Deleuze, 2003, p. 54). A memória se atualiza no presente, pois sua natureza é essencialmente narrativa. Luiz Costa Lima ressalta que toda narrativa é referencial e interpretativa, o que implica uma dupla temporalidade: "Referindo-se ao que passou, a narrativa aponta para o tempo originário da matéria do relato. Interpretativa do que passou, inscreve-o em um tempo que não é outro senão o de sua própria organização narrativa" (Lima, 1991, p. 144). Por causa disso, será sempre falha a proposta de manter o passado congelado em um tempo distante, já que, ao referir-se a ele, a memória o recria em uma narrativa do presente. Isso basta para que a narrativa da infância de Gaspar Dias fracasse em seu propósito, mas não explica por si só o fracasso da que ele cria para Emilio veja - a narrativa do bastardo.

Como já dito, a narrativa do bastardo possui uma contradição, que consiste na criação da imagem de uma figura paterna perfeita e intocável e o desejo de estabelecer contato com ela. Sempre que nos deparamos com o desconhecido, somos apresentados a informações novas, outrora invisíveis. O encontro com esse Outro implica uma quebra na imagem anteriormente construída. Essa ideia é bastante simples e possui corroborações no nosso cotidiano - pessoas que admirávamos de longe, ao nos aproximarmos, podem se revelar mais ou menos interessantes do que aquilo que prometiam, mas nunca exatamente o que era esperado; essa aplicação dentro dos princípios da narrativa, contudo, mostra-se um pouco mais complexa.

Partiremos de um exemplo no cinema: no filme Contatos imediatos de terceiro grau, de Steven Spielberg, a narrativa, articulada a partir de personagens diferentes, segue em direção a um objeto bastante claro, que são os seres de outro planeta. Todo o movimento do filme é em direção a esse contato com o objeto de desejo, que chega de fato a ocorrer. $\mathrm{O}$ que acontece quando as personagens finalmente atingem seu propósito e encontram aquilo que tanto procuravam? O filme se encerra. Godard criticava o filme de Spielberg nesse ponto, pois 
justamente no momento em que algo deveria acontecer, a narrativa chegava ao fim. O que Godard não levava em conta era que, naquele instante, a imagem perfeita havia se construído e a narrativa precisava se encerrar para que nada corresse o risco de sair da ordem e se desconstruir. Eis um exemplo de uma narrativa clássica que, sustentada por uma ordem rígida e sólida, mesmo que pertencente a uma realidade distante de nosso mundo cotidiano, em momento algum deseja outra condição para si a não ser de verdade única e inquestionável.

Gaspar Dias busca construir uma narrativa clássica tal qual a de Spielberg, mas sua narrativa é apenas uma dentro de um romance que possui propósitos diferentes para seu protagonista. Ao entrar em contato com seu objeto de desejo, a narrativa de Barco a seco não se encerra: ela vai além e revela o vazio dessa experiência. Isso ocorre no momento em que Gaspar descobre o duplo de Emilio Vega; a figura paterna que almejava construir para refazer seu romance pessoal se mostra traidora, não é mais única e perfeita. Ao trazer Emilio Vega do passado para o presente, dá-se o inevitável encontro com um outro Vega, representado por Inácio Cabrera. O pintor não teria morrido, toda a construção em torno do fim de sua vida seria uma fraude, e a narrativa que Gaspar criou para Vega não seria nada mais que uma perpetuação da fraude criada, a princípio, pelo próprio Vega ao se transformar em Inácio.

Inácio Cabrera atuou no subsolo ao longo de décadas, na glória do anonimato, na delícia do tipo de poder que só um sabotador desfruta. De lá, fez subir à tona, sempre no momento certo, ora uma peça autêntica, ora um capítulo cem por cento inventado da biografia de Vega, ora uma meia-verdade, um borrão de dúvida, um pano suspeito respingado com o sangue do pintor ou com uma reles tintura cor de barro. Inácio acompanhou a criação do mito passo a passo e se consagrou à vitória da heresia, antes mesmo que os adoradores de Vega pudessem instaurar os cânones do culto legítimo. Mil vezes Inácio afogou Vega, mil vezes empurrou sua cabeça para baixo da água para que não pudesse respirar, mil vezes os cabelos do pintor ondularam entre os dedos abertos de Inácio, enquanto as bolhas de respiração cortada ferviam em volta da sua mão (Figueiredo, R., 2001, p. 182).

A verdade que sustentava a narrativa entra em contato com outra verdade, que a desconstrói. Ao abrir a porta do passado, não há como 
evitar que, por esse espaço, outras verdades retornem ao presente. A busca necessária leva a uma traição inevitável: "Há sempre a violência de um signo que nos força a procurar, que nos rouba a paz. A verdade não é descoberta por afinidade, nem com boa vontade, ela se trai por signos involuntários" (Deleuze, 2003, p. 14-15). O penúltimo capítulo do romance de Rubens Figueiredo celebra o duplo da verdade, a instabilidade da narrativa e as ruínas do romance - como exaltou Octavio Paz (1996, p. 74): "O teatro e o romance contemporâneos não cantam um nascimento e sim um funeral: o de seu mundo e o das formas que engendrou". As ruínas, ao modo dos teóricos desconstrucionistas, fazem romper as fronteiras que classificavam o universo literário e o impunha a uma estrutura lógica binária, como o real e o imaginário, o verdadeiro e o falso. Barco a seco não apenas manifesta essa condição, mas - por seu caráter autorreflexivo e autoquestionador - busca celebrá-la e combatê-la, afirmá-la e questionála em um incessante movimento de construção e desconstrução da narrativa: "A literatura para os desconstrucionistas testemunha a impossibilidade de que a linguagem venha a fazer algo mais do que falar sobre o seu próprio fracasso, como os bêbados tediosos. A literatura é a ruína de toda referência, o cemitério da comunicação" (Eagleton, 2001, p. 201).

Dos bêbados que lamentam seu fracasso, contudo, poucos são os que decidem encerrar sua trajetória na Terra e cometem suicídio após se confrontarem com as frustrações pessoais. Desde novos objetivos a novas fantasias para velhos objetivos, a vida segue. Igualmente, após se apresentar como mera ruína, a narrativa não adquire uma impotência eterna, sendo ainda capaz de seguir em frente. Como no conto Ruínas circulares, de Jorge Luis Borges (2006), no qual um mago, habitante de uma terra em ruínas, destruída por um incêndio, confere a si próprio a missão de sonhar um ser humano ideal e construir algo em meio ao vazio. Após dias de intensa dedicação, prestes a atingir seu propósito, ele é consumido pelo mesmo fogo que deu origem a tudo: um processo incessante de construção e desconstrução, sendo que a interrupção imposta por essa segunda jamais impede o retorno à primeira. Em Barco a seco, Gaspar Dias pede a Inácio Cabrera a prova definitiva de que ele é Emilio Vega, mas tal verdade irrefutável, a única capaz de estabelecer um fim definitivo à narrativa, lhe é negada: 
Assim Inácio foi embora, ciente de que não só havia me revelado uma pintura incompleta, como também me deixara de posse de um segredo que eu não podia digerir, que eu não seria capaz de retraduzir nos termos da minha teoria. Inácio sabia ter atraído minha curiosidade para uma ratoeira expressa na forma de um desafio ao meu silêncio, um compromisso de sigilo que já era, só ele, metade de uma traição (Figueiredo, R., 2001, p. 183).

A nova verdade não é mais perfeita que a anterior. A narrativa é sempre capaz de prosseguir, pois a verdade que a destrona é tão frágil quanto a que a sustentava. Da mesma forma que a busca da criança pelo pai é interminável, por mais frustrações e obstáculos que surjam pelo caminho, não há alternativa para Gaspar Dias a não ser seguir em frente, construindo e reconstruindo suas narrativas. A velhice de Inácio Cabrera marca a fragilidade da nova verdade, que não perdurará por muito tempo. Inácio é o pai reencontrado por Gaspar, mas é um pai imperfeito, vivo, humano; ele precisa deixar de existir para que a busca prossiga na reconstrução da figura paterna. Como ele próprio afirma: "Minha lealdade era com o pintor - o pintor, quem quer que ele fosse, onde quer que ele estivesse" (Figueiredo, R., 2001, p. 186), ou seja, ele só deve satisfação à própria fantasia. E sendo a fantasia uma construção pessoal, a narrativa de Gaspar, assim como toda a ficção, se legitima por si só.

A morte de Inácio Cabrera representa a retomada da narrativa, a reconstrução das ruínas. Com o pai ausente, a figura materna volta a cumprir o seu papel - Angelina escapa da falência, sua galeria de arte se salva com novas pinturas de Vega deixadas por Inácio. Algumas delas, analisadas por Gaspar, apresentavam-se como falsas, mas o perito age na contramão e classifica todas como verdadeiras. Para que haja narrativa, para que haja ficção, é necessário ser cúmplice do falso e trair as supostas verdades: "Mais do que simplesmente silenciar, minha tarefa de agora em diante era esquecer tudo: só no esquecido podia subsistir alguma verdade" (Figueiredo, R., 2001, p. 187).

O último capítulo de Barco a seco é a narrativa da suposta morte de Emilio Vega no mar. As ruínas circulares da literatura atingem o ponto final que é, ao mesmo tempo, o ponto de partida. A morte é ambígua, pois é fim e também é recomeço, salvação: "Eles vão levá-los aos trancos para uma ponta de granito onde, quem sabe, mesmo machucado, e contra toda razão, e até contra a mera decência, ele espera mais uma vez se salvar" (Figueiredo, R., 2001, p. 191). Não importa se sua ordem se mostra 
abalada, se segue o caminho oposto da razão e do bom senso, a ficção é sempre capaz de se reconstruir e se salvar, pois a sua ordem obedece a uma lei interna, desonestamente elaborada por e para si própria.

\section{Referências}

BACHELARD, Gaston (1993). Poética do espaço. São Paulo: Martins Fontes.

BAKHTIN, Mikhail (2013). Problemas da poética de Dostoiévski. Rio de Janeiro: Forense Universitária.

BORGES, Jorge Luis (2006). Fiç̧ões. São Paulo: Companhia das Letras.

BORGES, Jorge Luis (2007). Outras inquisições. São Paulo: Companhia das Letras. DELEUZE, Gilles (2003). Proust e os signos. Rio de Janeiro: Forense.

EAGLETON, Terry (2001). Teoria da literatura: uma introdução. São Paulo: Martins Fontes.

FIGUEIREDO, Rubens (2001). Barco a seco. São Paulo: Companhia das Letras.

FIGUEIREDO, Vera Lúcia Follain (2001). Crise da narrativa e ilusionismo verbal. Semear, Rio de Janeiro, v. 7. Disponível em: <http://www.letras.pucrio.br/unidades\&nucleos/catedra/revista/7Sem_17.html>. Acesso em: 19 dez. 2013.

FREUD, Sigmund (1997). Gradiva de Jensen e outros trabalhos. Rio de Janeiro: Imago. (Edição standard brasileira das obras psicológicas completas de Sigmund Freud, v. IX).

HUYSSEN, Andreas (2000). Seduzidos pela memória: arquitetura, monumentos, mídia. Rio de Janeiro: Aeroplano.

LIMA, Luiz Costa (1991). Pensando nos trópicos: (Dispersa Demanda II). Rio de Janeiro: Rocco.

PAZ, Octavio (1984). O labirinto da solidão e post-scriptum. Rio de Janeiro: Paz e Terra.

PAZ, Octavio (2013). Os filhos do barro: do romantismo à vanguarda. São Paulo. Cosac Naify.

PAZ, Octavio (1996). Signos em rotação. São Paulo: Perspectiva.

RABELLO, Ivone Daré (2007). Barco a seco, de Rubens Figueiredo: certezas e enganos da imagem identitária. Terceira Margem, Rio de Janeiro, n. 16, p. 128-141. 
ROBERT, Marthe (2007). Romance das origens, origens do romance. São Paulo: Cosac Naify.

ŽIŽEK, Slavoj (1997). The plague of fantasies. New York: Verso.

Recebido em julho de 2015.

Aprovado em outubro de 2015.

\section{resumo/abstract/resumen}

\section{O retorno ao passado em Barco a seco e o jogo de construção e desconstrução narrativa}

\section{Carlos Palacios}

O artigo realiza uma análise do livro Barco a seco (2001), de Rubens Figueiredo, tendo como foco o conflito entre as diversas narrativas que são construídas no interior do romance a partir da mediação do protagonista Gaspar Dias. O conflito se dá em torno do desejo de Gaspar de retornar ao passado e construir diversas narrativas baseadas em preceitos realistas, almejando uma verdade única e sólida, ao mesmo tempo que, para isso, necessita recorrer ao ato de criação, que estabelece uma relação distinta com a verdade. Para entender essa contradição, que gera o jogo de construção e desconstrução da narrativa, o trabalho apoia-se principalmente nas ideias de Octavio Paz sobre as relações da obra de arte com o tempo, no debate que Andreas Huyssen propõe em torno da musealização do passado e na teoria da história do Bastardo, de Marthe Robert.

Palavras-chave: narrativa, ficção, verdade, desconstrução, Rubens Figueiredo.

\section{The return to the past in Barco a seco and the construction and deconstruction of the narrative cycle}

\section{Carlos Palacios}

The essay analyzes Rubens Figueiredo's book Barco a seco (2001) focusing on the conflict between the many narratives that are built into the novel through the mediation of the protagonist Gaspar Dias. The conflict occurs around Gaspar's desire to return to the past and build narratives based on realistic precepts, aiming at a unique and solid truth. Nonetheless, in order to achieve this he must resort to the act of creation, which establishes a distinct relationship to the idea of truth. To understand this contradiction, which generates the construction and deconstruction of the narrative cycle, the essay focuses its analysis on the ideas of Octavio Paz about the relations between the work of art and time, on the 
discussion that Andreas Huyssen proposes about the musealization of the past and on Marthe Robert's theory of the Bastard's story.

Keywords: narrative, fiction, truth, desconstruction, Rubens Figueiredo.

\section{El retorno al pasado en Barco a seco y el juego de construcción y deconstrucción narrativa}

\section{Carlos Palacios}

El ensayo analiza el libro Barco a seco (2001), de Rubens Figueiredo, y se centra en el conflicto entre las muchas narrativas que se construyen en la novela a través de la mediación de la protagonista Gaspar Dias. El conflicto se produce en torno a la voluntad de Gaspar de volver al pasado y construir narrativas basadas en preceptos realistas, buscando una verdad única y sólida, mientras que él debe recurrir al acto de la creación, que establece una relación distinta con la idea de la verdad. Para entender esta contradicción, que genera la construcción y deconstrucción del ciclo narrativo, el ensayo centra su análisis en las ideas de Octavio Paz sobre las relaciones de la obra de arte con el tiempo, en la discusión que Andreas Huyssen propone sobre la musealización del pasado y en la teoría de la historia del Bastardo de Marthe Robert.

Palabras clave: narrativa, ficción, verdad, deconstrucción, Rubens Figueiredo. 